\section{An analysis of preschedule-change rates in a multiple variable-interval schedule ${ }^{1}$}

$D A V I D$ A. GIBSON, University of Tennessee at Martin, Martin, Tenn. 38237, and JESSE B. MLLBY, JR., University of Alabama Medical School, Birmingham, Ala. 35203

Pigeons were trained on a multiple variable-interval schedule having different scheduled frequencies of food reinforcement. Preschedule change rates in relatively long and short components were examined in the presence and absence of an exteroceptive "warning" stimulus. Predicted rate shifts occurred independently of component duration but only in the presence of the "warning" stimulus.

Pliskoff (1961) has demonstrated that a variable-interval (VI) schedule of positive reinforcement will generate an increased response rate in a short, discriminated interval before a shift to a lower frequency-of-reinforcement VI schedule and a decreased rate in a discriminated interval before a shift to a higher frequency-of-reinforcement VI schedule. There is evidence suggesting that these rate-change effects are not dependent upon differential reinforcement frequencies during the preschedule change "warning" stimuli (Pliskoff, 1963).

If the passage of time in a VI component can come to serve as a "warning" stimulus for the onset of the next VI component, Pliskoff's $(1961,1963)$ data would predict a rate increase immediately preceding the transition to a VI component of low reinforcement frequency and a rate decrease immediately preceding the transition to a VI component of high reinforcement frequency when the components of a multiple variable-interval, variable-interval (mult VI VI) schedule alternate successively in the absence of any exteroceptive "warning" stimulus.

In their analysis of contrast effects in a mult-VI-VI schedule in which the average interreinforcement intervals were divergent, Nevin \& Shettleworth (1966) obtained results contrary to those predicted by Pliskoff's (1961, 1963) findings. Variable-interval response rates declined immediately preceding a shift to a lower frequency-of-reinforcement VI component and increased preceding a shift to a higher frequency-of-reinforcement VI component. Whereas Pliskoff $(1961,1963)$ employed an exteroceptive, preschedule change "warning" stimulus and long (15-min) schedule components, Nevin \& Shettleworth (1966) used relatively short (3-min) components and did not program a preschedule change "warning" stimulus. Accordingly, either of the two procedural differences could have produced the disparate effects. The present study attempts a rapprochement of these findings by investigating preschedule change response rates in the presence and absence of exteroceptive "warning" stimuli and by manipulating the duration of high and low frequency-of-reinforcement components in a mult-VI-VI schedule.

\section{SUBJECTS}

Two adult male Silver King pigeons ( $P$ - 1 and P-2) served as Ss. Both birds were experimentally naive at the beginning of the study and were maintained throughout at $80 \%$ of their free-feeding body weights. APPARATUS

The experimental chamber was a pigeon box of the type described in detail elsewhere (Ferster \& Skinner, 1957).

\section{PROCEDURE}

The Ss were trained to stable performance on a mult VI VI schedule for food reinforcement in which two VI components with average interreinforcement intervals of $1 \mathrm{~min}$ (mult VI 1 VI 1) alternated successively. During the first component of the two-ply multiple schedule, the response key was transilluminated with red light. The response key was lighted green during the alternate component. For P.1, each component lasted $15 \mathrm{~min}$. For P-2, the components were of $3 \mathrm{~min}$ duration. Sessions terminated after $1 \mathrm{~h}$ for both Ss. Following stability on mult VI 1 VI 1 , an adaptation procedure was initiated in which the houselights were extinguished during the final quarter interval of each component. Adaptation training continued until extinction of the houselights had no disruptive effects on baseline rates of responding.

The experiment proper began when the schedule for both $\mathrm{Ss}$ was changed to mult VI 1 VI 10. The response key was lighted red during VI 1 and green during VI 10. Sessions terminated after $2 \mathrm{~h}$. The Ss were trained to stability on mult VI 1 VI 10 in the absence of any preschedule change "warning" stimulus. At this point, the "warning" stimulus was introduced, i.e., the houselights were extinguished during the final quarter interval of each component. The preschedule change "warning" stimulus remained in effect until response rates again stabilized.

In a second phase of the experiment, both Ss were returned to mult VI 1 VI 1 with the component durations reversed. For P-1, each component lasted $3 \mathrm{~min}$. For $\mathrm{P}-2$, the components were of $15 \mathrm{~min}$ daration. Subsequent experimental manipulations included retraining to stability on mult VI 1 VI 1, readaptation to the "warning" stimulus, and retesting on mult VI 1 VI 10 in the absence and presence of the preschedule change "warning" stimulus. In all, both Ss were tested on mult VI 1 VI 10 under four treatment conditions: (1) 3-min component duration-"warning" stimulus present, (2) 3-min component duration-"warning" stimulus absent, (3) $15 \cdot \mathrm{m} \mathrm{i} \mathrm{n} \mathrm{com} \mathrm{pon} \mathrm{e} \mathrm{t}$ duration-“warning" stimulus present, (4) $15 \cdot \mathrm{min} \quad \mathrm{com} \mathrm{pone} \mathrm{nt}$ duration-"warning" stimulus absent.

\section{RESULTS AND DISCUSSION}

Averaged stable performances on mult VI 1 VI 10 with component durations of 3 and $15 \mathrm{~min}$ are shown in Fig. 1. The findings replicate those of both Pliskoff $(1961,1963)$ and Nevin \& Shettleworth (1966), i.e., the predicted preschedule change effects occurred only in the presence of an exteroceptive "warning" stimulus. During the "warning" stimulus, response rates increased before a shift to

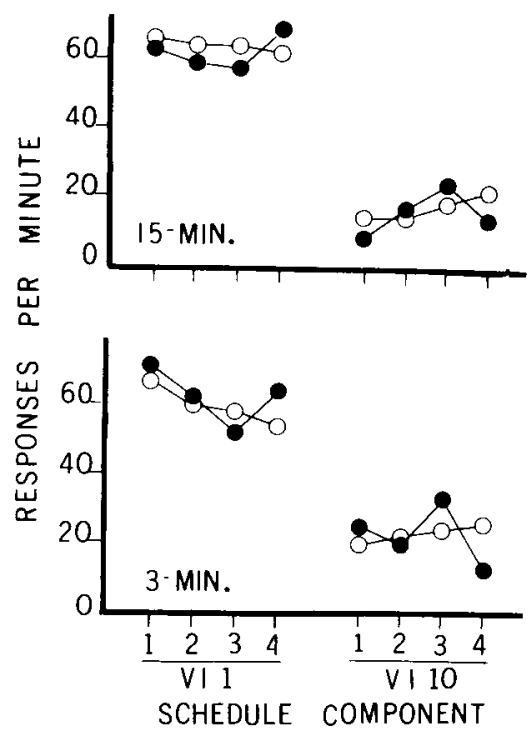

Fig. 1. Averaged stable rates of responding in successive quarter intervals of mult VI 1 VI 10 with 3-min and 15-min component durations. Each data point represents the grand mean of the final five sessions in which a preschedule-change "warning" stimulus did (black circle) or did not (open circle) occur during the last quarter interval of each component. 
VI 10 and decreased before a shift to VI 1 . Converse preschedule change effects occurred in the absence of the "warning" stimulus. The directions of rate changes generated by the "warning" stimulus were the same for both component durations, although the trends were slightly more pronounced for 3-min components than for 15-min components.

The prediction that response rates would accelerate before a shift to a VI component of low reinforcement frequency and decrease before a shift to a VI component of high reinforcement frequency in the absence of an exteroceptive "warning" stimulus was not confirmed. The passage of time in VI components did not exert the same discriminative control over behavior as did the programmed preschedule change stimulus.

Whereas the data do suggest the relevance of the presence of an exteroceptive "warning" stimulus in accounting for the discrepancy between the results of the aforementioned investigators, it should not be inferred that temporal cues and exteroceptive stimuli cannot exert comparable discriminative control over behavior in the pigeon (Ferster \& Skinner, 1957). Indeed, had the test conditions been imposed for a longer period, the differences might well have been negligible. In any event, a more definitive statement regarding the role of "warning" stimuli in preschedule change rate shifts must await further investigation involving appreciably more exposure to the same general procedure.

\section{REFERENCES}

FERSTER, C. B., \& SKINNER, B. F. Schedules of reinforcement. $\mathrm{New}$ York: Appleton-Century-Crofts, 1957.

NEVIN, J. A., \& SHETTLEWORTH, S. J. An analysis of contrast effects in multiple schedules. Journal of the Experimental Analysis of Behavior, 1966, 9, 303-315.

PLISKOFF, S. S. Rate-change effects during a pre-schedule-change stimulus. Journal of the Experimental Analysis of Behavior, 1961, 4, 383-386.

PLISKOFF, S. S. Rate-change effects with equal potential reinforcements during the "warning" stimulus. Journal of the Experimental Analysis of Behavior, 1963, 6, 557-562. NOTE

1. Reprints may be obtained from David A. Gibson, Department of Psychology, University of Tennessee at Martin, Martin, Tenn. 38237.

\section{Conspecific odors as cues for runway behavior in mice}

\author{
STEPHEN F. DAVIS, King College, \\ Bristol, Tenn. 37620
}

Fourteen mice served as $S$ in a test of the odor hypothesis. All Ss received 104 acquisition trials administered in a double-alternation sequence of reward and nonreward. The results indicated that the mice were able to learn the double-alternation sequence when odor cues were maximized and unable to do so when odor cues were minimized. These results are seen as being comparable to those reported when other species were used as Ss.

Ludvigson \& Sytsma (1967) reported a study in which Ss learned to perform appropriately (fast to reward, slow to non reward) a double-alternation task supposedly on the basis of qualitatively or quantitatively different olfactory cues that were differentially emitted on reward (R) and nonreward $(\mathrm{N})$ trials. Other studies (McHose \& Ludvigson, 1966; Morrison \&
Ludvigson, in press; Ludvigson, 1969; and Davis \& Ludvigson, 1969) have tended to support the odor hypothesis. Also, a recent study by Topping \& Cole (1969), using Mongolian gerbils as Ss, corroborated the odor hypothesis.

The present study was designed to extend the generality of the odor hypothesis by using a different species, the albino mouse, as the $\mathbf{S}$. As far as possible, the procedure reported by Ludvigson \& Sytsma (1967) was employed.

\section{SUBJECTS}

Fourteen male albino mice (FDP/SW strain), purchased from Mouse House, Inc., were used as Ss. The Ss were housed in individual cages with water always available. During the experiment, the Ss were maintained at $85 \%$ ad lib body weight.

\section{APPARATUS}

A $60.96-\mathrm{cm}$ straight runway served as the apparatus. Guillotine doors separated a $15.24-\mathrm{cm}$ white startbox and a $15.24-\mathrm{cm}$ black goalbox from a $30.48-\mathrm{cm}$ black run section. Raising the starting door activated a Standard Electric timer that was stopped by breaking a photoelectric beam located over the goal cup. The apparatus was $50.8 \mathrm{~mm}$ wide and $63.0 \mathrm{~mm}$ tall. Plexiglas lids covered the entire apparatus.

\section{PROCEDURE}

Upon receipt from the supplier, all Ss were placed on ad lib food for 1 week. At the end of this time, deprivation was begun. All Ss were maintained throughout the experiment at $85 \%$ of their mean ad lib weights. When all Ss had reached $85 \%$ of their ad lib weights, pretraining was begun. Pretraining, which consisted of handling and taming, habituation to the reward pellets, and habituation to the unbaited apparatus, lasted for 4 days. At the end of pretraining, the Ss were assigned randomly to two equal groups: $E$ and $C$. Furthermore, each $\mathrm{S}$ was assigned randomly a permanent ordinal position (1-7) within his group. During the experiment, the Ss received all trials in this order, and all Ss in a group received a given trial before the next trial was administered. All the daily trials for a particular group were given before the other group was run. The groups alternated with respect to which was run first daily.

All Ss received $52 \mathrm{R}$ and $52 \mathrm{~N}$ trials at the rate of $8(4 R 4 N)$ trials per day. A reward was one 45-mg Noyes pellet. On N trials, each $\mathrm{S}$ was confined to the goalbox for $20 \mathrm{sec}$. The schedules for the daily administration of trials are presented in Table 1. As can be seen from Table 1, Groups $\mathrm{E}$ and $\mathrm{C}$ differed with respect to the within-trial $R, N$ sequence. Group $E$ had a homogeneous within-trial sequence (odor maximizing conditions), while Group C had a heterogeneous within-trial sequence (odor minimizing conditions). To prevent odor from one trial affecting performance on the next trial, the entire apparatus was swabbed with a damp sponge before the running of $S 1$ in both groups.

\section{RESULTS AND DISCUSSION}

Figure 1 shows the mean speeds (meters per second) for the four trials of the double-alternation sequence. As in previous studies, the double-alternation patterning (fast to $\mathrm{R}$, slow to $\mathrm{N}$ ) was very pronounced for Group E, but virtually nonexistent for Group C. Analysis of variance yielded a significant Reinforcement Conditions ( $R$ vs $N$ ) by Groups interaction $(F=10.63$, df $=1 / 12, p<.01)$. Subsequent Newman-Keuls analysis indicated that the patterning was significant $(p<.01)$ for Group E, but not for Group C.

These results would appear to support the conclusions made by the previous studies (Ludvigson \& Sytsma, 1967; 